\title{
“MILITARISM IS A MOVEMENT OF RETROGRESSION": THE FEMINIST PACIFISM OF JANE ADDAMS, MABEL ST CLAIR STOBART AND ROSE MACAULAY IN WORLD WAR I
}

\author{
“EL MILITARISMO ES UN MOVIMIENTO DE RETROGRESIÓN”: EL PACIFISMO \\ FEMINISTA DE JANE ADDAMS, MABEL ST CLAIR STOBART Y ROSE \\ MACAULAY EN LA I GUERRA MUNDIAL
}

Jaime Francisco Jiménez Fernández

Universidad de Sevilla

\section{Abstract:}

The telling of the Great War (1914-1918), mainly through the point of view of combatants, is one of the best scenarios exemplifying how women have been obviated and censored throughout history. Moreover, the engagement of pacifist women in the conflict has been doubly belittled due to a misinterpretation of the term 'pacifism'. Consequently, this paper aims at re-examining the origins and values of pacifism from a western perspective and giving visibility to pacifists Jane Addams, Mabel St Clair Stobart and Rose Macaulay and their efforts during the event.

\section{Keywords:}

World War I, women, pacifism, gender

\section{Resumen:}

El relato de la Gran Guerra (1914-1918), principalmente desde el punto de vista de los combatientes, es uno de los mejores escenarios que ejemplifican cómo las mujeres han sido obviadas y censuradas a lo largo de la historia. Además, la participación de las mujeres pacifistas en el conflicto ha sido doblemente menospreciada debido a una mala interpretación del término "pacifismo". En consecuencia, este artículo tiene como objetivo reexaminar los orígenes y valores del pacifismo desde una perspectiva occidental y dar visibilidad a las pacifistas Jane Addams, Mabel St Clair Stobart y Rose Macaulay y sus esfuerzos durante el evento.

\section{Palabras clave:}

Primera Guerra Mundial, mujeres, pacifismo, género 


\section{INTRODUCTION}

When facing the experiences of Anglophone pacifist women during the Great War, there are various difficulties that need to be taken into account. The first one is the number of pacifist women. Though not as ample as, for instance, the number of civilians who enlisted in the Voluntary Aid Detachment (known as VADs) or women involved in industrial work, there is still a somewhat large corpus of women to consider. Once this task is carried out, special attention needs to be paid to the ones who have produced any kind of work and to its quality as well as to those who contributed to the pacifist movement through speeches or simply by vindicating the ceasefire. Yet, this already provides a wide margin of authors to research about in future studies.

Moreover, sometimes pacifist women's perspective has not been the same throughout their accounts and works. For instance, authors such as Vera Brittain (1893-1970) or Mabel St Clair Stobart (1862-1954) do not embrace pacifism until they have a firstperson experience of the war and its atrocities. Also, most of this material has not been published yet, therefore it is laborious to access it. For instance, most of women's letters or diaries concerning pacifism are only held at the archives of the Imperial War Museum in London.

Besides, critical support is also somewhat lacking in this field. Though Peace Studies are ample, they tend to focus prominently in what peace is and how it can be achieved: Webel and Galtung (2007), Amster et al. (2015) or Barash and Webel (2016), among others. Within the Great War studies, its centenary and the revisionist context of the period have helped to draw attention to women. Yet, the focus of attention is placed on the different jobs women took for the very first time, the horrors experienced as a VAD or the trauma caused by personal losses, such as Brybon (2013), Asselin (2016), Dumenil (2017) or Wynn and Wynn (2017), to name a few, who are primarily concerned about women's roles which broke stereotypes and conventions. As pacifism has been wrongly interpreted as passivism, most publications, such as Grayzel and Liggins and Nolan (2019), including the above-mentioned ones, obviate pacifist women and, if mentioned, they are proportionally inferior to the women related to patriotism, conscription, industrial work and so on. The example that best proves this fact is Vera Brittain's experience of the war: though turning into a fervent pacifist, most scholars, such as Bostridge (2014) and, most importantly, even the film adaptation ${ }^{1}$ of Brittain's own Testament of Youth (1933), directed by James Kent and released in 2014, have focused on her war rhetoric of patriotism and heroism, on doing 'her bit' as a VAD

1 This is of utmost relevance, as the film adaptation has probably been the biggest exposure of Brittain's accounts to the general public. Indeed, the leading actress who interpreted the role of Brittain was star Alicia Vikander, whose popularity was at its peak around that time, as she also stared in The Danish Girl (2015), which earned her the Oscar award for Best Supporting Actress. 
and the horrors she suffered, while dismissing her pacifist activity which is, indeed, included in her aforementioned memoir ${ }^{2}$. Thus, the need of a study centered simply on pacifist women ${ }^{3}$ and their efforts during World War I becomes stronger than ever.

\section{JUSTIFICATION}

As historian Hew Strachan notes, World War I "has become one of the most unassailable divisions in the compartmentalization of the past" (2004: 132) and, therefore, a matter of study for numerous scholars. Following this definition, it is simple to understand why the events that lasted from 1914 until 1918 are also known as The Great War, as it was the first conflict that affected such a large proportion of the globe and this, along with the technological advances of the time, turned it into one of the most lethal events in history. As a consequence, not only has the war to end all wars become the perfect scenario for numerous accounts based on personal and real experiences, but also for the massive production of fictional material dealing with the matter. Yet, only combatants' perspective of the conflict is the focus of most studies.

One may wonder why and how this happened. In the early 20th century, the discourses on femininity were still inserted within the old-fashioned imageries of the Victorian period. This meant that women should conform to the private sphere, where women were to be confined to the privacy and safety of their homes, following the parameters set by the famous poem Angel in the House by Conventry Patmore (1854), where women's aforementioned attitude and position in society were established.

As a consequence, women's own experience about the conflict used to be of no relevance. However, due to the feminist intervention in the historical and literary canon, women's experience throughout history has gained visibility and valor. When it comes to the Great War, women's experiences have been brought to the public eye, in general, by numerous publications and scholarly researches such as those by Susan R. Grayzel (2002), Vivien Newman (2014) or Christine E. Hallet (2016), to name but a few.

2 Brittain's experience can be divided into two different moments: her experience as a VAD and that as an absolute pacifist. Once the war broke out, Brittain decided to contribute to the effort as a VAD, therefore, she did not only support the women's movement but she was also an example of a woman breaking from the private sphere and stepping into the public one in a hyper-masculinized context: war. As a matter of fact, Brittain's engagement in the women's movement gained recognition, and she became a feminist journalist who tried to reconcile both feminism and pacifism in her works. Nevertheless, and as time passed by, she realized that political contributions seeking for peace, such as the League of Nations, were advocated to fail, as the upcoming events of the 1930s proved. Consequently, she turned her efforts towards the pacifist movement alone and religion and reason became her main motivations. This may be a reason why scholars have tended to focus on one side of her story, as Brittain's feminist and political contributions may be more attractive to scholars as it breaks with burdens in a more striking way than her absolute pacifist attitude. For more information, see Mellown, M. (1985).

3 This research, as mentioned, is contextually focused on American and British women. Nevertheless, this necessity of visualizing pacifist women may be applied to women of all the belligerent and neutral countries that asked for the ceasefire during WWI. 
However, there seems to be a spectrum of women whose actions have not, or at least not to the same extent, been acknowledged yet: pacifists. Indeed, pacifist women had to face a greater censorship. On the one hand, as women, they were considered to be inferior and their claims were socially disregarded. On the other hand, as most women supported the war (either in the battlefront or in the home front), pacifist women's discourse found itself doubly belittled. Moreover, the pacifist movement has usually been wrongly associated with passivity. Consequently, interest in these women was rare, as they were considered to suit within outdated stereotypes. As a result, even feminist have, sometimes, failed to pay the necessary attention to the actions carried out by this specific group that problematized the gender dynamics of the war context. This oblivion in which pacifist women have fallen into within the Great War context is proved when examining the publications regarding both women and WWI and their contents mentioned in the previous section.

However, and as it will be discussed below, there is an intersection between pacifism and feminism in the authors' experience that is worth addressing. Nonetheless, and as this paper aims to prove, pacifism is not passivism, a personality trait that has been traditionally assigned to women. Following this premise, it will be easier to both (de ) construct the motivation of pacifists and their actions within the Great War, as well as giving visibility to both the collective and their efforts.

\section{Methodology}

Following the necessity of achieving the aims previously discussed, the methodology implied in order to do so consists in examining the state quo of the literary canon of the Great War within a very specific context: Britain and the USA, which has already been addressed and referenced in the previous sections. Hence, and despite the fact that gynocriticism and the feminist intervention in the literary canon have provided some light upon a large extent of women's experiences within a male-associated event (Susan R. Grayzel (2002), Vivien Newman (2014) or Christine E. Hallet (2016)), there is still a minor group which is generally disregarded: pacifists, as previously mentioned. Thus, an analysis of why pacifists' efforts, especially those of women, have tended to fall into oblivion is necessary, as already proved.

This ultimately leads to a review of the etymological roots of the term 'pacifism' and the context of the word's origins. In order to do so, the theories of authors such as Clough (2007), Dosenrode (2008) or Lohmann (2017) will be referred to. By doing so, pacifism will be proved to be detached from the stereotypes of passivity that have been ill-associated to the movement and which has made critics, even feminist ones, to obviate pacifist women's activity. 
Once the aforementioned steps have been completed, the conclusions achieved regarding pacifism and its true active nature will be exemplified by the active contribution of the women, within the specific context of Britain and the United States in the Great War, of the selected corpus: Jane Addams ${ }^{4}$, Mabel St Clair Stobart and Rose McCauley. For so, their works, respectively, Women at the Hague (1915) ${ }^{5}$, The Flaming Sword in Serbia and Elsewhere (1916) and Non-Combatants and Others (1916) will be taken into account closely.

\section{Pacifism: Context and Revision}

Many (Cortright (2008), Galtung (2013), or Fox (2014), among others) have tried to provide a definition of what pacifism means, yet, scholars do not seem to agree on what it truly conveys. According to the Oxford English Dictionary, the term pacifism can be defined as a

[b]elief in or advocacy of peaceful methods as feasible and desirable alternatives to war; (espousal or advocacy of) a group of doctrines which reject war and every form of violent action as a means of solving disputes, esp. in international affairs. Also: advocacy of a peaceful policy or rejection of war in a particular instance. (OED, n.)

Following this definition, it is simple to infer that non-violent responses are expected from those who stand pacifism, especially in political contexts. Yet, there is no mention about the kind of actions pacifists are most likely to perform. Indeed, and historically, these actions have been wrongly associated to passivism, as non-resistance was misunderstood with no-action. However, this statement is far from being true, and a deep research about pacifism's roots illuminates the blind spots concerning public perception of the movement.

The term pacifism was first used around late $19^{\text {th }}$ - early $20^{\text {th }}$ centuries. Nonetheless, if attention is paid to the core meaning and etymological roots of pacifism ${ }^{6}$, Christianity has to be considered. As Friedrich Lohmann remarks, pacifism's origins are much older 'than the $20^{\text {th }}$ century as its "first appearance designates people and not a concept

4 It must be noted that, despite the fact that Addams is American, the pacifist movement of the USA was originated in very similar circumstances to the British (and to a larger extent, Europe) one. The different wars that took place during the $19^{\text {th }}$ century, the still present ideals of reason and equality of the Enlightenment, and the revival experienced in the Society of Friends (Quakers) were the reasons of the origins of the pacifist movement at both sides of the Atlantic. For more information regarding the origins of said movement in both countries, see Kennedy, T. (1984) and Cortright, D. (2008).

5 The three works have been accessed through digitalized versions of the original copies. This is stated in the references section.

6 This paper acknowledges that there are other forms of pacifism, including other cultures and religions such as Buddhism or Hinduism. Nevertheless, and due to the scope of this paper, the revision and contextual-dependence of the word 'pacifism' is focused on the western civilization, as it is the most immediate context of the corpus' authors. 
[...] As the New International Version puts it: 'Blessed are the peacemakers, for they will be called children of God"' (2017: 3).

Soren Dosenrode draws upon Childress's analysis on pacifism, as he points out to two crucial passages in the New Testament: "the words of Jesus in the Sermon on the Mount not to resist one who is evil (Matthew 5:39), and the words of Paul that he who resists the authorities resists what God has appointed and those who will resist will incur judgement (Romans 13:2)" (2008: 29). In consequence, "Christian disciples are called to turn the other cheek, not resist evil" (Clough 2007: 17).

Therefore, Childress believes that this Biblical life-style can be coined as "passive resistance" (quoted in Dosenrode 2008: 29), preventing Christians from taking any kind of action if it implies violence or aggression. This is the idea that the popular western imagery as accommodated throughout history about pacifism and pacifists: people who, from a passive standpoint, will do nothing but endure a certain situation even in spite of disagreeing with it. However, this passive understanding of pacifism and those who support it comes, as Dosenrode claims, from "a misinterpretation of Matthew 5:39"' (2008: 29).

Indeed, according to Dosenrode,

if the term 'resistance' implies efforts to effect or prevent social and political change, their actions might better be viewed as non-compliance or conscientious objection. Instead of passively obeying rulers, Christians have refused to comply with law, orders, or demands that conflict with God's will, usually accepting the consequences of non-compliance. (2008: 29)

Moreover, according to Bartsch's (1969) statement, the word pacifism is contracted from Latin words pax (peace) and facere (make), and disciples are called to be 'peacemakers' (Matthew 5:9). Therefore, a true Christian understanding of the word is far from signifying passivity, as it implies the willing act of making, it requires action (quoted in Dosenrode 2008: 30).

This erratic point of view needs to be highlighted, as, even though pacifism encompasses the act of making peace, pacifists are "often represented and criticized for their passivity, as pure bystanders, just waiting and observing while others are massacred" (Lohmann 2017: 3). As a consequence, pacifist women have found their actions neglected not by virtue of their sex but also because of the ill-interpretation of the cause they supported. This was even more evident throughout the course of World War I, as the stereotypes imposed on women were highly restrictive and their social position very limited. Nevertheless, this new light upon the term pacifism evidences that not only a revision of women's experience in WWI is required, but also, and especially, a revision of those whose actions were doubly disregarded. 


\section{The Great War and British and American Pacifism}

When facing the Great War, patriotism stands as one of the main guiding principles which allowed the war to move forwards. Indeed, Patriotism held that inspirational status during World War I as it enabled governments to make men enlist in hordes, fully equipped with high moral values and heroic ideals that governmental propaganda had instilled in their minds ${ }^{7}$. Yet, certain citizens, especially women, were able to overcome the burden of patriotism and tried to provide a closer image of what war really was.

However, governmental propaganda was so well-designed that even after years into the War, citizens still believed it was a righteous cause. As a result, "in 1916 the majority of writers were still refusing to contemplate what they saw. The existence of the War was taken-for-granted" (Tylee 1990: 107). Moreover, it was not until January 1916 that conscription became compulsory through the Military Service Bill, meaning that, until this moment, England had been able to make men enlist alone on the basis of patriotism for over one year and a half, despite already showing that the war was not a matter of few months as promised at its outbreak. As a consequence, this became the reason why the horrors of the event were not generally questioned, as they were considered to be a mere routine to achieve a higher purpose.

Consequently, pacifists were despised in a society which elevated abstract values such as heroism or patriotism, and as Tylee argues, "though it was legal it was never easy to be a conscientious objector or to help one" (1990: 53). This breach between those who supported the War and those who were against it was so intense that "there was felt to be more sympathy between English and German soldiers than between Englishmen at the Front and all other English women and men" (Tylee 1990: 54).

This is actually discussed in Virginia Woolf's radical pacifist essay Three Guineas (1938), where "women's participation in the war is denounced as a misguided and dangerous acceptance of militarism, brought about by the British woman's 'loathing' for the confinement of the private home: the rush to volunteer for service abroad; 'that amazing outburst in 1914', showed that 'unconsciously [women] desired our splendid war"' (Barrett 1993: 160-1). Basically, most British women sought the war as an opportunity to finally counterbalance themselves to men in a historical event, but a small portion of women, pacifists, considered the war as a way of aligning with bellicose masculine attitudes. Indeed, Woolf points out in Three Guineas that patriotism is the "one reason which prevails in order to bring about [an] overpowering unanimity" (2015: 94), that is, that the vast majority of men "are today in favour of war" (93). Still, she argues that there must be a difference between men's and women's notions of

7 This can be proven by the different posters that were created as a means of propaganda during the Great War, such as the ones of Saint George defeating the dragon. In order to have a clearer picture of these pieces of propaganda, visit the webpage of the Imperial War Museum: https://www.iwm.org.uk/ 
patriotism. As Woolf points out, it is not the same to be "educated men" (94) than being "the daughters of educated men" (100) as "[woman's] position in the home of freedom has been different from her brother's" (94). Nevertheless, she is well-aware of the fact that "[s]till some 'patriotic' emotion, some ingrained belief in the intellectual superiority of her own country over other countries may [have] remain[ed]" (99), considering this to be the reason why such a large number of women rushed to volunteer to do war-work without hesitating.

Taking all this into consideration, it seems obvious that being a pacifist, whatever your motives were, was not an easy task during World War I in Britain . However, it is very interesting to note that the conception of pacifism was not the same in the United States than in the United Kingdom, as the former did enter the war later on (April 6, 1917) and pacifism was a much rooted movement in the country, due to its origins and recent bellicose events, such as the Civil War. This will be proven with the selection of pacifist women chosen, as it contains the experience of both American and British pacifist women.

\section{American and British Pacifist Women}

Having already analyzed the true context and meaning of the term 'pacifism' as well as the overall context of the Great War in both Britain and the United States, the focus of attention will be placed on the three different pacifist women that are part of the present corpus: Jane Addams, Mabel St Clair Stobart and Rose Macaulay. Addams has been chosen as she represents the most participative role of women within pacifism, so she can be considered as a role model who needs to be taken into account. On the other hand, Stobart and Macaulay have been chosen because of their active participation in the war effort and, especially, because the actions they performed were hand in hand with their pacifist beliefs.

$$
\text { 6.1. Jane Addams }
$$

Jane Addams (1860-1935) is known as the 'mother' of social work. An American pioneer, she is well-known because of her leading role in women's suffrage and world peace. Addams played a paramount, though somehow disregarded role during WWI, because it did not follow the patriotic trend of the period.

Addams was against WWI and criticized American President Woodrow Wilson's decision of declaring war to Germany. While many "criticized pacifists' passivity and argued that they had no constructive role to play in advancing Wilson's ideals of democracy" (Agnew 2017: 6), Addams would recall her deepening sense of "spiritual alienation" (Agnew 2017: 6) as the war progressed. As a matter of fact, Addams describes in her memoir Peace and Bread in Time of 
War (1922) how "[s]olitude has always had its demons" (143), making her and other pacifists feel as outsiders, as the majority of people supported Wilson's call for arms. This led her to feel as if she was trapped in an "unnatural desert into which the pacifist was summarily cast out" $(143)$.

As author Agnew recalls, "[f]rom the outset of the war in Europe, Addams acted boldly and contrarily to accusations that pacifists were passive and lacked patriotism. In 1915, she joined the Fellowship of Reconciliation, a new Christian pacifist organization" (2017: 7).

Addams' pacifism is easily distinguished because of her drawing on the language of biology, as she was highly influenced by Darwin: "[s]he offered the image of biological growth proceeding from a differentiated 'mother cell' as a metaphor for pacifists' impetus for social change" (Agnew 2017: 14). Moreover, Addams had a personal interpretation of this mother cell which was related to woman's innate sensitiveness to human life. Furthermore, Addams was convinced of the sanctity of life, which was a primer in her pacifist beliefs. According to Addams, "[t]housands of people in this United States and Europe had become so convinced that the sanctity of life was an accepted tenet of civilization that they deemed war had become forever impossible" (1915: 65). Nevertheless, and as a consequence of the outbreak of the war, "[t]his belief [was] rudely overturned, and we [were] at the foot of the ladder, beginning again to establish the belief that human life is sacred above all else that the planet contains" (1915: $65)$.

Thus, the sanctity of life is Addam's former defense of pacifism, which also goes hand in hand with feminism, as Addams links woman's position and role in society to the pacifist movement. According to Addams, she would never "assert that women are better than meneven in the heat of suffrage debates [she has] never maintained that — but we would all admit that there are things concerning which women are more sensitive than men, and that one of these is the treasuring of life" (1915: 65). All this sensitiveness became clear due to the caring attitude of women towards the young, the elders and people in special needs. Thus, Addams appealed to this metaphor to foster women's activism against the destruction of war. Indeed, Addams believed that a "state founded upon tribal ideals of patriotism ha[d] no place for women within its councils" (1915: 64). Consequently, Addams argues that "[w]omen have a right to protest against the destruction of that larger ideal of the state [...] in which they can play no part" (1915: 64). For that purpose, the presence of women in political and social spheres is required, as they are the ones to stop brutal force through equality.

When it comes to the Great War, it must be noted that, for Addams, the bellicose event contradicted her ideals of humanism, community and peace. Having met Leo Tolstoy (18281910) at his Russian farm, Addams spent most of her time thinking about war and peace, which led her to attend to peace conferences and to publish Newer Ideals of Peace (1907), where she provides a positive idea of peace as a dynamic social process. As a consequence, and following her emphasis on the role of women within pacifism, she chaired the Women's Peace Party and, 
once WWI broke out, she presided over the first International Congress of Women at The Hague ${ }^{8}$, Netherlands, in 1915. She then met with the heads of neutral nations in order to communicate them the resolutions of the Congress, and she also lent her support to the American Union Against Militarism. Some of the resolutions that were reached at the Congress are of ultimate relevance, as they highlight how some women, and in this concrete case, Addams, believed that the women's movement's aims and pacifism's aims were, somehow, intertwined. Thus, Addams, along with the other women who attended the Congress, asked for suffrage, which would provide women the possibility to have access to politics and, consequently, to propose solutions concerning mediation and arbitration for international affairs. Indeed, and as recorded in the resolutions reached at the Congress,

Since the combined influence of the women of all countries is one of the strongest forces for the prevention of war, and since women can only have full responsibility and effective influence when they have equal political rights with men, this International Congress of Women demands their political enfranchisement. (Addams et al. 1915: 154)

By doing so, Addams clearly positioned herself in favor of the pacifist and the women's movements in a time when notions of patriotism and heroism were exalted, consequently risking her prestigious reputation by opposing World War I. Indeed, before WWI, Addams was probably the most beloved woman in America as The Independent's poll "Who among our contemporaries are of the most value to the community?" (1913) proves: she turned out to be second. Nevertheless, once she opposed America's involvement in World War I, newspaper editors called her a traitor and a fool.

After Addams ruined her popularity for opposing militarism and blind patriotism, even before the USA joined the Allies, she continued to advocate for world peace. Addams's reputation was restored during the last years of her life. She continued to run Hull House and work on other peacemaking activities like the presidency of the Women's International League for Peace and Freed om which kept her travelling abroad in order to convince national officials of the importance of peace. Finally, Addams was rewarded for her efforts with the Nobel Peace Prize in 1931.

\subsection{Mabel St Clair Stobart}

Mabel St Clair Stobart (1862-1954) is widely-known for her commitment as an aidworker. Indeed, as Smith notes, Stobart "became the first woman in the First World

8 The Congress was held from April 28, 1915 to May 1, 1915. The relevance of this Congress cannot be overlooked, as it marked the beginning of a number of both international and national associations which pleaded for both universal suffrage and peace, such as the Women's International League for Peace and Freedom (WILPF) or its local British branch, the Women's International League (WIL). For more information regarding the Hague Congress, see Addams et al. (1915). 
War to lead a field hospital unit to the front line" (2000: 47). Yet, little attention is placed on her pacifist ideas.

Stobart's pacifism is made explicit in her novel The Flaming Sword in Serbia and Elsewhere, published in 1916. However, Stobart was not a pacifist at first. Rather, she turned into pacifism once she eye-witnessed the war atrocities. Stobart's first encounter with war was during the Balkan War, to which she went with her mind open "for impressions of so-called glories of war" (19169: 5). Nevertheless, and after the seven weeks that she spent there, what she found were "butchered human beings, devastated villages, a general callousness about the value of human life" (5). This experience prepared her for WWI and to incessantly criticize militarism. Indeed, and as scholars Alison Fell and Ingrid Sharp remark, Stobart's "seven weeks of active service in the Balkans was to be a dress rehearsal" (Fell and Sharp 2007: 163) when compared to her forthcoming experience in World War I.

Stobart's Christian beliefs became therefore the basis of her pacifist discourse present in The Flaming Sword. As Stobart mentions (ix), It is inspired by one episode from the Bible (Genesis 3: 22-24) where God placed a flaming sword at the east of the Garden (Eden) so as to prevent Adam and Eve from entering the Garden again. According to Stobart, "the way to the Tree of Life, is past the flaming sword, which turns north, south, east, and west; and we, in these days, can well believe it" (317). This reference resembles the situation of humankind during WWI: it is impossible to get to the Tree of Life (the source of eternal life and God's Grace) because of the "flaming sword", a metaphor for war.

Moreover, Stobart considers that the society of her time needs forgiveness for they have sinned against the sanctity of human life: they have held patriotism and nationalism as their idols, and as long as they did not stop worshipping them, death would be their routine. As a consequence, Stobart believes that, "[w]e Christians [...] must destroy militarism" (1); militarism means the failure of humankind.

Yet, Stobart believes that women's judgment is disregarded because of a 'lack of experience'. She also thinks that some pacifists' main problem is that they 'don't act, they talk; and until their talk is translated into action, they will be ineffective in conquering war" (193). As a result, she dares to state that "action is an universal language which all can understand" (4). Stobart acts by serving in different hospitals and doing what any human being is expected to do: aim for the "preservation, not destruction, of life" (3). She understood that pacifism is not passivism, and that active resistance can be achieved through a firm conviction in the cause of peace.

Stobart, as Addams did, also links this necessity of protecting life with the women's movement. According to her, "in the eyes of woman, war also means the negation of civilisation

9 All of Stobart's quotations are from her novel The Flaming Sword in Serbia and Elswhere (1916). 
and progress" (312). For Stobart, the women's movement deals both with suffrage and salvation. Man-dominated society had only caused numerous wars as history proves. However, if women were also to have a voice in the public sphere, they would subvert this situation. Stobart is also able to understand that war affects everyone, as "modern militarism involves tortures and extermination, not only of the fighting, but of the non-fighting portion of the population" (314).

Stobart's pacifist ideas and ideals are not only linked to her religious beliefs, but also to feminism. At the very first page of her work, Stobart states that "militarism can only be destroyed with the help of Woman. In countries where Woman has least sway, militarism is most dominant. Militarism is maleness run riot" (13). Thus, Stobart, just as Addams, believes that a larger presence of women in institutions and political contexts may downgrade the scale of bellicose events, helping women to finally take part in roles traditionally associated to men.= As a result, Stobart argues that,

Therefore, it is good that Woman shall put aside her qualms, and go forth and see for herself the dangers that threaten life.

Therefore it is good that Woman shall record, as Woman, and not as neuter, the things which she has felt, and seen, during an experience of militarism at first hand. (14)

As Stobart states, "militarism is a movement of retrogression" (13), and therefore not only would the story and the history of World War I be incomplete without women's experience of the war, but also humankind would be advocated to repeat the same mistakes, just as the fail of the aforementioned League of Nations and the outbreak of World War II prove. Moreover, and as scholars Fell and Sharp point out, Stobart usually exposes both her experience and that of the women within her unit in Serbia as an example of women's capability of carrying out tasks that were not, according to the stereotypes of the period, associated to women. Thus, Stobart "never concedes that they are not at least equal to men, and uses the hospital to show how she is demonstrating this equality at every opportunity" (Fell and Sharp 2007: 166).

In summary, and bearing in mind Stobart's feminist pacifism, she reaches the conclusion that men have failed to extinguish the flame of the sword, the possibility of saving lives and fulfilling God's mission, as physical force is not the answer. Women, on the contrary, who have "the interests of human kind, at heart", [suggest], with all humbleness, that if human kind is ever to reach the Tree of Life, the spiritual power of woman must be added to the physical force of man" (317). As a result, women's movement hand in hand with pacifism would foster equality and human stability.

6.3. Rose Macaulay 
Rose Macaulay (1881-1958) is a very well-known artist because of her prolific career along which she published novels, poetry, essays and works of history among other. It is relevant to bear in mind that Macaulay's writings and personal life were also highly influenced by Christianity, a prominent feature within pacifists and a primordial inspiration of her pacifistic attitude and responses to war.

Macaulay experienced the War when she first enlisted as a VAD and as a land girl, though she ended up becoming a civil servant in the Italian section of the Ministry of Information's propaganda department. As Stobart, Macaulay's pacifist ideas come from her encounter with the atrocities of the war: she had to confront the mutilated bodies of the wounded soldiers during her service as a VAD and the pain caused by the loss of one of her best friends, the trench poet Rupert Brooke. Taking these facts into account, her fiction novel Non-combatants and Others (1916) is helpful in order to exemplify her pacifist beliefs, which are related to her identity both as an artist and as a Christian.-

At the beginning of the story, Alix Sandomir, its main character, is presented as an artist, as she first appears drawing. Moreover, information about her physical condition is provided, as she is affected by a physical disability: "[s]he had had a diseased hipjoint as a child, which had left her right leg slightly contracted" (Macaulay 1916 : 20). Alix's discrimination is represented intersectionally as a woman, an artist and a disabled person. When compared to her family, who are all thinner because they are "leading busy and useful lives, full of war activities" (21), Alix is said to be "a lazy little beggar. Alix is hopeless; she does nothing but draw and paint [...] the Girl who isn't doing her bit" (22). Moreover, she feels, like Addams, out of place while war-talking goes on, which leads her to go "indoors and up to bed [...] shivering, as if she was cold" (26).

Indeed, Alix tries to refuge herself from the horrors of war in her art. Yet, it is important to note that, as Stobart did realize, everybody is affected by war, and despite her efforts to escape, her very language is infected by the war rhetorics, as when she describes the letters from the front as "bullets and bits of shrapnel crashing into her world" (23). This problematic situation makes Alix come closer to war and the general agenda of the country, very much against her initial reluctance.

However, Alix is well-aware that "[p]ainting and war don't go together" (29), so she seeks for an alternative route to flee from war hysteria. Consequently, Alix feels she needs to do "[s]omething against war, I want to be doing ... Something to fight it, and prevent it coming again..." (98). It is at this moment that an intersection between feminism and pacifism takes place, having been foreshadowed throughout the rest of the novel in the figure of Alix's mother, Daphne Sandomir, who is a pacifist activist. Yet, Macaulay's work presents an overwhelming amount of characters who mock 
feminism, especially those who inhabit in Violette's villa: Mrs. Frampton and her daughters Evie and Kate. Indeed, especial attention needs to be drawn upon how Evie refers to Miss Simon, a suffragette: “[t]hat fatty in a sailor blouse,' Evie, who observed clothes, commented. 'I should think they'd be glad of a change from her. She's a suffragette, and talks the weirdest stuff; she's as good as a play to listen to..."' (37).

Nevertheless, these interventions against feminism are contrasted by those of Miss Simon, who in desperation complains about none of the characters realizing about the war machine and how women, and therefore the women's movement, must act. Indeed, Miss Simon claims that "'[y]ou none of you see. Except her'-she indicated Alix -" (48). Thus, and as Joyce Van Damme (2017) remark, Alix finds in feminism and pacifism a way to break from old standards and conventions, as she breaks from the stereotypical figure of both the hero and the woman 'doing her bit'. Moreover, and as scholar Genevive Brassard highlights, Macaulay's characterization of Alix falls within that of feminist writers, as they consists on a subversion "of cultural assumptions about femininity by creating heroines who defy conventions, resist traditional scripts [...], and assume their rightful place alongside men as engaged observers of, or active participants in, the war" (Brassard 2004: 2). As a result, Macaulay's pacifism is, just as Addam's and Stobart's, inherently linked towards feminism and vice-versa.

For this reason, and as Van Damme (2017) points out, luckily, and throughout the novel, Alix is related to different people who are against the War and fight, with no arms, against it, such as her mother, Daphne Sandomir, a passionate pacifist who travels around the world trying to educate people in peace, or Mr. West, Alix's brother's roommate and a clergyman, thus emphasizing the need to create alliances and a sense of community among those who share the anti-militaristic creed. The influence of these two people, along with Alix's feelings of alienation and spirituality, lead her to state, at the very ending of the novel that: "Christianity, so far as I can understand it, is working against war too; must be, obviously. So I shall join the Church.... That's all" (120). By doing so, Alix participates in the conflict but from a perspective that suits her spirituality and intellectuality as an artist: fighting for peace.

\section{CONCLUSION AND FURTHER RESEARCH}

As the testimonies of Addams, Stobart and Macaulay prove, British and NorthAmerican women pacifists, even in the case of renamed Jane Addams, were obviated in a society which glorified masculinist notions of patriotism and heroism. The revision of pacifist women needs, indeed, to go on hand in hand with a revision of the term pacifism, which, as argued above, is far from signifying passivism. The attitudes and choices described in the sections dedicated to the three different women show that, through a diverse range of contributions, all the actions performed by these women 
could never be considered as submissive or unresisting, as they actively engaged pacifism by different means (as a leader of the movement, as an aid-worker or as a writer) but with an ultimate and common cause: the denounce of violence and the pursuit of the so-long awaited peace. Moreover, pacifism and feminism share their agendas in their common bonding around equality and the presence of women in more political and social contexts.

To end, it is necessary to mention that these women are merely a small representation of the whole western pacifist movement, which was not only inspired by individual and personal motivations but also supported by larger groups, such as Quaker communities, parishes, or socialist groups. Therefore, if the scope is widened and more pacifist women's actions are studied, similar experiences will emerge from neglected accounts and experiences. By doing so, both pacifism and pacifist women in World War I may be re-considered and brought to the public eye in order to value their contribution to one of the most decisive events in history. Moreover, this reconsideration of the pacifist movement and its members does not only apply to Britain and the USA. Indeed, its scope can be widened and the rest of belligerent and neutral countries may be included. Thus, a multi-cultural approach within the same culture (western) and a renewed reading of both pacifism and pacifist women's actions may help to build new bridges between the critics who had been ill-informed about the movement and its members, consequently providing visibility to minor groups which have been, and still are, silenced. By doing so, a more inclusive and holistic vision of the Great War may be achieved.

\section{REFERENCES}

Abrams, L. "Ideals of Womanhood in Victorian Brittain", BBC. August 9, 2001. [Accessed online on September 22, 2020], http://www.bbc.co.uk/history/trail/ victorian_britain/women_home/ideals_womanhood_01.shtml.

Addams, J. Women at the Hague, The MacMillan Company, New York, 1915. PDF file, Library of Congress. [Accessed online on November 30, 2020], https://www.loc.gov/ item/15025357/

Addams, J. Peace and Bread in Time of War, New York, The Macmillan

Company, 1992

Addams, J. What War is Destroying. In Addams's Essays and Speeches on Peace. Eds. Marilyn Fischer and Judy D. Whipps. Bristol, England, Thoemmes Press, 2003.

Agnew, Elizabeth N. “A Will to Peace: Jane Addams, World War I, and 'Pacifism in Practice"', Peace and Change, 42:1 (2017), pp. 5-31. 
Amster, R., Finley, L. and Pries, E. Peace Studies between Tradition and Innovation, Cambridge Scholars Publishing, United Kingdom, 2015.

Asselin, K. C. Women in World War I, Abdo Publishing, Minnesota, 2016.

Barash, D. P. and Webel, C. Peace and Conflict Studies, SAGE, United Sates off America, 2016.

Brybon, G. Women Workers in the First World War, Routledge, USA, 2015.

Brassard, G. Becoming a War Heroine: Feminist Revision and Cultural Resistance in Women's Literature of the First World War, Proquest Dissertations Publishing, 2004. [Accessed online on November 30, 2020], https://www.proquest.com/docview/305208912

Bostridge, M. Vera Brittain and the First World War: The Story of Testament of Youth, Bloomsbury, Great Britain, 2014.

Boxwell, D. A. "The (M)Other Battle of World War One: The Maternal Politics of Pacifism in Rose Macaulay's Non-Combatants and Others". Tulsa Studies in Women's Literature, 12:1 (1993), pp. 85-101.

Clough, D. L. and Stiltner, B. Faith and Force: A Christian Debate about War, Washington, D.C., Georgetown University Press, 2007.

Cortright, D. Peace: A History of Movements and Ideas, Cambridge University Press, New York, 2008.

Dosenrode, S. Christianity and Resistance in the 20th Century: From Kaj Munk and Dietrich Bonhoeffer to Desmond Tutu, Boston, BRILL, 2008.

Dumenil, L. The Second Line of Defense: American Women and World War I, University of North Carolina Press, 2017.

Friedrich, L. "Myth and Reality: Pacifism's Discourse on Violence Revisited", Studies in Christian Ethics, 31:2 (2017), pp. 186-200.

Fell, A. and Sharp, I. "The Woman who Dared: Major Mabel St Clair Stobart", The Women's Movement in Wartime: International Perspectives, 1914-19, Palgrave Macmillan;2007. [Accessed on December 4, 2020], http://search.ebscohost.com/login. aspx?direct=true\&db=nlebk\&AN=224361\&lang=es\&site=ehost-live\&scope=site

Fox, M. A. Understanding Peace: A Comprehensive Introduction, Routledge, New York, 2014.

Galtung, J. and Dietrich, F. John Galtung. Pioneer of Peace Research, Springer, New York, 2013.

Grayzel, S. R. Women and the First World War, Harlow, Longman, 2002.

Goldstein, Joshua S. War and Gender: How Gender Shapes the War System and Vice Versa, Cambridge University Press, United Kingdom, 2003. 
Hallett, C. Nurses Writers of the Great War, Manchester, Manchester University Press, 2016.

Kennedy, T. C. “The Quaker Renaissance and the Origins of the Modern British Peace Movement, 1895-1920", Albion: A Quarterly Journal Concerned with British Studies, 16:3 (Autumn, 1984), pp. 243-272.

Liddle, P. Britain's Great War Experience: Life at Home and Abroad 1914-1918, Barnsley, Pen and Sword Military, 2014.

Liggins, E. and Nolan, E. Women's Writing of the First World War, Routledge, New York, 2019.

Macaulay, R. Non-combatants and Others, PDF file, London, Hodder and Stoughton, 1916, The Project Gutenberg EBook. [Accessed online September 5, 2020], http://www. gutenberg.org/ebooks/35807.

Mellown, M. “One Woman's Way to Peace: The Development of Vera Brittain's Pacifism", Frontiers: A Journal of Women Studies, 8:2 (1985), pp. 1-6.

Newman, V. We Also Served: The Forgotten Women of the First World War, Great Britain, Pen and Sword History, 2014.

Shields, P. M. Jane Addams: Progressive Pioneer of Peace, Philosophy, Sociology, Social Work and Public Administration, Switzerland, Springer, 2017.

Smith, A. K. “'The Mists Which Shroud these Questions': Mabel St Clair Stobart, the First World War and Faith", Literature and History, 20:2 (2011), pp. 1-15.

Smith, A. K. The Second Battlefield. Women, Modernism and the First World War, Manchester, Manchester University Press, 2000.

Strachan, H. The Outbreak of the Great War, Oxford, Oxford University Press, 2004.

Testament of Youth. Directed by James Kent, performances of Alicia Vikander, BBC Films, 2014.

Tylee, C. M. The Great War and Women's Consciousness: Images of Militarism and Womanhood, London, Macmillan, 1990.

Stobart, M. St. C. The Flaming Sword in Serbia and Elsewhere, London, Hodder and Stoughton, 1916. PDF file, Archive. [Accessed online October 1, 2019], https:// archive.org/details/flamingswordinse00stobrich.

Van Dame, J. Women's Writing of World War I. Discourses of Feminism and Pacifism in Rose Macaulay's Non-Combatants and Others and Vera Brittain's Testament of Youth (unpublished thesis), Ghent, University of Ghent, 2017.

Webel, C. and Galtung, J. A Handbook of Peace and Conflict Studies, Routledge, New York, 2007. 
Woolf, V. A Room of One's Own and Three Guineas. Edited with an Introduction and Notes by Anna Snaith, Oxford University Press, United Kingdom, 2015.

Wynn, S. and Wynn, T. Women in the Great War, Pen and Sword Military, Great Britain, 2017. 